\title{
The Relationship Between Leisure Time Management and Perceptions of Boredom
}

\author{
Veli Ozan Çakir ${ }^{1, *}$ \\ ${ }^{1}$ Faculty of Sport Sciences, Sports Management ABD, İstanbul University-Cerrahpaşa, Turkey \\ *Correspondence: Faculty of Sport Sciences, Sports Management ABD, İstanbul University-Cerrahpaşa, Turkey. \\ E-mail: veliozancakir@gmail.com
}

Received: April 15, 2019

Accepted: May 18, 2019 Online Published: June 5, 2019

doi:10.5430/wje.v9n3p38

URL: https://doi.org/10.5430/wje.v9n3p38

\begin{abstract}
The purpose of this research is to examine university students' leisure time management and perceptions of boredom according to various factors and to put forward the relationship between those two concepts. The test group of the research has been selected with purposive sampling among students from Istanbul University-Cerrahpaşa Faculty of Sport Sciences and 170 "Male" and 82 "Female" students with an average age of 21,71 \pm 3,10 have volunteered to take part. In the research "Leisure Time Management Scale," which has been developed by Wang et al. (2011) and adapted into Turkish by Akgül and Karaküçük (2015), and "Leisure Boredom Scale," which has been developed by Iso-Ahola and Weisseinger (1990), and adapted to Turkish by Kara et al. (2014), has been used. In order to determine the personal information of participants the percentage and frequency methods; to determine whether the data has normal distribution or not the Shapiro Wilks normalcy test has been applied and after concluding, that the data is conformable with the parametric test conditions, MANOVA and Pearson Correlation tests have been used for data analysis. According to the analysis; in view of gender variable, in both leisure time management and leisure boredom perceptions scale a significant difference has been observed $(p<0.05)$. In view of age variable, in the "Programming" subdimension of leisure time management and in all subdimensions of leisure boredom perception scale a significant difference has been observed $(p<0.05)$. In view of wealth variable, in the "Leisure time manner" and "Programming" subdimensions of leisure time management scale a significant difference has been observed but no difference has been observed in leisure time perception. Finally, a negative and meaningful relationship has been observed between the two scales. In conclusion it is possible to claim, that the leisure time management and boredom perception of participants has had significant differences in view of some variables and that when they can manage their leisure time, they are satisfied.
\end{abstract}

Keywords: university students, leisure time management, perception of boredom in leisure time

\section{Introduction}

In an everchanging world, the physical and mental attributes of people have changed over time. In this changing and improving world, leisure time concepts and recreation has been a way that people use to protect their physical and mental health. (Demirel et al., 2017, Serdar et al., 2017). Definitions regarding leisure time vary for individuals taking part in events. (Howe \& Carpenter, 1985; Demirel \& Harmandar, 2009). Individuals engage in leisure time activities of their own accord. The purpose and value of activities are different for everyone. Some desire to spend their leisure time vivaciously and cheerfully, some to be in touch with their friends, to have new experiences, to have a taste of what creativity is, to achieve social utility and thus they attend leisure time activities (Serdar and Ay, 2016; Aydoğan and Gündoğdu, 2006). To be able to engage in recreational activities a person needs to have free time, which is the time not spent working and dealing with essential needs, and it varies from person to person, and it has a subjective meaning (Karaküçük, 2005, Gürbüz ve Handerson, 2013, Demirel ve Harmandar, 2009; Demirel et al., 2017). Leisure boredom perception, which decreases participation in leisure time activities and sustainability of attended activities, has been defined by Iso-Ahola and Weissinger (1990) as "insufficient motivation for available leisure time experiences, low stimulation, no incentive or subjective perception that none of those are sufficient." In other words, it is the unhappiness or dissatisfaction people feel, when they cannot find an activity, which sparks their interest (Yaşartürk et al., 2017). To have free time and the activities people do in their spare time directly or 
indirectly affects other dimensions and values of their lives. Karaküçük (2008) summarizes this issue by saying, "Leisure time could be compared to a double-edged sword." When used positively it might conduce to personal and social improvement, otherwise to problems such as depression and disorder. Thus it is obvious that 'youth,' which is a large segment of the population, needs to take heed of it much more. Being a university student means one is going through a tough phase, where they are developing their personality, adopting the national and universal values of society, adapting, taking economic, social and academic responsibilities on the way to become an adult, and reaching maturity. In this difficult process, studies about different variables, which affect their psychological wellbeing and the satisfaction they get from life becomes even more important (Soyer et al., 2016). The system of education today is not solely about future professions. Schools not only relate knowledge, but are also liable to socialize individuals (Ekinci et al., 2018). Today, leisure time management has become a way of life. It is for this reason that undergraduate years is the most important period, when behaviour patterns are shaped, which will be maintained for many years to follow. Engaging in and leading recreational activities will help raise strong, well-disposed and edified individuals (Ağaoğlu \& Eker, 2006) and have a positive impact on many fields (job satisfaction, life satisfaction, family life etc.) of their lives (Huang \& Carleton, 2003; Aradahan \& Lapa, 2010). In the light of such information, the purpose of the study is to investigate leisure time management skills and leisure boredom perceptions of university students.

\section{Method}

\subsection{Research Method}

Survey model has been used in the research. Survey method portrays a past or still existing situation as it was or still is and it aims to define the investigated event, person or object in its own terms and to observe it without changing the current conditions (Karasar, 2012).

\subsection{Test Group}

The test group of the research has been selected with non-probability purposive sampling among students from Istanbul University-Cerrahpaşa Faculty of Sport Sciences and 170 "Male" and 82 "Female" students with an average age of 21,71 $\pm 3,10$ have volunteered to take part in the study.

\subsection{Data Collection Tools}

In the research "Personal Information Form," "Leisure Time Management Scale," and "Leisure Boredom Perception Scale" have been used as data collection tools.

\section{Personal Information Form}

"Personal Information Form," which has been developed by researchers, has been used to obtain information about the gender, age, grade, weekly leisure time duration and wealth level of participants.

\section{Leisure Time Management Scale}

In order to assess the leisure time management of participants; "Leisure Time Management Scale," which has been developed by Wang et al. (2011) and adapted to Turkish by Akgül and Karaküçük (2015), has been used. It is a five-point Likert scale, has 15 articles and 4 subdimensions. The subdimensions are respectively; Setting and Objective and Method, Leisure Time Manner, Programming and Assessing. The scale's Cronbach Alpha internal consistency coefficient is 0.83 but, in our research, we have found it to be 0.80 .

\section{Leisure Boredom Perception Scale}

In order to assess the individual differences between leisure time perceptions of participants; "Leisure Boredom Perception Scale," which has been developed by Iso-Ahola and Weisseinger (1990) and adapted to Turkish by Kara et al. (2004), has been used. It is a five-point Likert scale, has 10 articles and 2 subdimensions. The subdimensions are respectively; Satisfaction and Boredom. The scale's internal consistency coefficient has been found to be 0.83 in our research.

\subsection{Data Assessment}

Statistical analyses within the scope of the research has been conducted via SPSS 20 statistics package. In order to determine the distribution of personal information of participants descriptive statistics (frequency, arithmetic average, standard deviation); to determine if data had normal distribution Shapiro Wilks normalcy test has been conducted. Once it has been determined, that the data were in concordance with the parametrical test conditions, to analyse the data; to determine the differences based on leisure time management and leisure boredom level of participants the 
independent MANOVA test; to determine the relationship between leisure time managements and boredom perception levels the Pearson Correlation test has been conducted.

\section{Findings}

Table 1. Distribution of Participants' Personal Information

\begin{tabular}{lccc}
\hline Variables & & F & \% \\
\hline \multirow{3}{*}{ Gender } & Male & 170 & 67,5 \\
& Female & 82 & 32,5 \\
Age & Total & $\mathbf{2 5 2}$ & $\mathbf{1 0 0}$ \\
& $17-20$ & 160 & 42,1 \\
& $21-23$ & 98 & 38,9 \\
& $24-26$ & 48 & 19,0 \\
Grade & Total & $\mathbf{2 5 2}$ & $\mathbf{1 0 0}$ \\
& Freshman & 40 & 15,9 \\
& Sophomore & 88 & 34,9 \\
& Junior & 71 & 28,2 \\
Weekly Leisure & Senior & 53 & 21,0 \\
Time Duration & Total & $\mathbf{2 5 2}$ & $\mathbf{1 0 0}$ \\
& $1-5$ Hours & 22 & 8,7 \\
& 6-10 Hours & 86 & 34,1 \\
& $11-15$ Hours & 66 & 26,2 \\
Wealth Level & Hours and more & 78 & 31,0 \\
& Total & $\mathbf{2 5 2}$ & $\mathbf{1 0 0}$ \\
& Low & 40 & 15,9 \\
& Normal & 170 & 67,5 \\
& High & 42 & 16,7 \\
& Total & $\mathbf{2 5 2}$ & $\mathbf{1 0 0}$ \\
\hline
\end{tabular}

Table 1 shows statistical findings with regards to gender, age, grade, weekly leisure time duration and wealth level of participants. Analysis indicates of the participants; $67,5 \%$ are "Male", 32,5\% are "Female," $42,1 \%$ are "between the ages of $17-20, " 34,9 \%$ are "Sophomores," that $34,1 \%$ have " $6-10$ " hours of leisure time per week and that $67,5 \%$ have "Normal" wealth level.

Table 2. Distribution of Scale Scores

\begin{tabular}{lcccccccc}
\hline & $\begin{array}{c}\text { Number of } \\
\text { Articles }\end{array}$ & $\mathbf{n}$ & Average. & Sd & Skewness & Kurtosis & Min. & Max. \\
\hline Leisure Time Management & 15 & 252 & 2,48 & 0.60 & 0.16 & 0.27 & 1.00 & 4.00 \\
Setting an Objective and Method & 6 & 252 & 2,35 & 0.81 & 0.20 & 0.55 & 1.00 & 4.50 \\
Leisure Time Manner & 3 & 252 & 1,89 & 0.84 & 0.95 & 0.35 & 1.00 & 5.00 \\
Programming & 3 & 252 & 3,22 & 0.12 & 0.42 & 0.20 & 1.00 & 5.00 \\
Assessment & 3 & 252 & 2,58 & 0.91 & 0.19 & 0.62 & 1.00 & 5.00 \\
Leisure Boredom Perception & 10 & 252 & 2,88 & 0.50 & 0.49 & 0.28 & 1.00 & 4.50 \\
Boredom & 5 & 252 & 2,35 & 0.81 & 0.35 & 0.65 & 1.00 & 4.00 \\
Satisfaction & 5 & 252 & 3,42 & 0.92 & 0.45 & 0.52 & 1.00 & 5.00 \\
\hline
\end{tabular}

Within the scope of the research, in leisure time management scale 'Leisure Time Manner' subdimension has the lowest average with 1.89 and 'Programming' subdimension has the highest average with 3.22. When we look at the leisure boredom perception scale scores, we see that 'boredom' subdimension has the lowest average with 2.35 and 'Satisfaction' subdimension has the highest average with 3.42. In view of the skewness and kurtosis of the scales, it would be safe to assume that the data has normal distribution. 
Table 3. MANOVA Test Results as per Participants' Gender

\begin{tabular}{|c|c|c|c|c|c|c|c|}
\hline & \multicolumn{2}{|l|}{$\begin{array}{l}\text { Female } \\
(N=82)\end{array}$} & \multicolumn{2}{|c|}{$\begin{array}{c}\text { Male } \\
(N=170) \\
\end{array}$} & \multirow[b]{2}{*}{ Sd } & \multirow[b]{2}{*}{$\mathbf{F}$} & \multirow[b]{2}{*}{$\mathbf{p}$} \\
\hline & Average. & Sd. & Avg. & Sd & & & \\
\hline Leisure Time Management & 2.23 & 0.64 & 2.60 & 0.55 & $1-359$ & 7.564 & $.000^{*}$ \\
\hline Setting an Objective and Method & 2.00 & 0.79 & 2.52 & 0.79 & $1-359$ & 5.504 & $.000 *$ \\
\hline Leisure Time Manner & 1.67 & 0.72 & 2.00 & 0.88 & $1-359$ & 5.850 & $.004 *$ \\
\hline Programming & 3.21 & 0.25 & 3.23 & 0.62 & $1-359$ & 3.032 & 0.61 \\
\hline Assessment & 2.28 & 0.94 & 2.72 & 0.87 & $1-359$ & 4.755 & $.000 *$ \\
\hline Leisure Boredom Perception & 2.82 & 0.52 & 3.02 & 0.48 & $1-359$ & 2.286 & $.000 *$ \\
\hline Boredom & 2.31 & 0.99 & 2.38 & 0.71 & $1-359$ & 3,363 & .089 \\
\hline Satisfaction & 3.26 & 0.92 & 3.74 & 0.88 & $1-359$ & 2,512 & $.000 *$ \\
\hline
\end{tabular}

Table 3 shows MANOVA results concerning leisure time management and boredom perceptions in view of participants' gender. Analysis shows as per gender variable its basic influence in both leisure time management and leisure boredom perceptions is significant $\left[\left[\lambda=0.848, \mathrm{~F}_{(6,245)}=7.304, \mathrm{p}<0.05\right]\right.$. With regards to coefficient level, the "Setting an Objective and Method" $\left[\mathrm{F}_{(1,359)}=5.504, \mathrm{p}<0.05\right]$, "Leisure Time Manner" $\left[\mathrm{F}_{(1,359)}=5.850, \mathrm{p}<0.05\right]$, and "Assessment" $\left[\mathrm{F}_{(1,359)}=4.755, \mathrm{p}<0.05\right]$ subdimension scores of leisure time management scale show significant difference. Again within the context of coefficient level when we take a look at leisure boredom perception; "Satisfaction" $\left[\mathrm{F}_{(1,359)}=2.512, \mathrm{p}<0.05\right]$ subdimension shows a significant difference. In both scales, in the subdimensions where a significant difference has been observed, average scores of male participants are higher than those of female participants.

Table 4. MANOVA Test Results as per Participants' Ages

\begin{tabular}{|c|c|c|c|c|c|c|c|c|c|}
\hline & \multicolumn{2}{|c|}{$\begin{array}{l}\text { 17-20 Age } \\
(N=106)\end{array}$} & \multicolumn{2}{|c|}{$\begin{array}{l}\text { 21-23 Age } \\
(N=98)\end{array}$} & \multicolumn{2}{|c|}{$\begin{array}{l}24 \text { and Over } \\
(N=48)\end{array}$} & \multirow[b]{2}{*}{ Sd } & \multirow[b]{2}{*}{$\mathbf{F}$} & \multirow[b]{2}{*}{$\mathbf{P}$} \\
\hline & Avg. & Sd & Avg. & Sd & Avg. & Sd & & & \\
\hline Leisure Time Management & 2.42 & 0.63 & 2.52 & 0.45 & 2.59 & 0.45 & $2-249$ & 2.286 & .489 \\
\hline Setting an Objective and Method & 2.31 & 0.84 & 2.36 & 0.83 & 2.43 & 0.74 & $2-249$ & 1.782 & .694 \\
\hline Leisure Time Manner & 1.96 & 0.84 & 1.91 & 0.89 & 1.68 & 0.72 & $2-249$ & 1.299 & .139 \\
\hline Programming & 3.51 & 0.60 & 3.29 & 0.34 & 3.03 & 0.76 & $2-249$ & 2.304 & $.017 *$ \\
\hline Assessment & 2.51 & 0.93 & 2.68 & 0.59 & 2.53 & 0.62 & $2-249$ & 8.476 & .397 \\
\hline Leisure Boredom Perception & 2.84 & 0.60 & 2.91 & 0.44 & 2.93 & 0.37 & $2-249$ & 7.862 & .498 \\
\hline Boredom & 2.47 & 0.78 & 2.40 & 0.85 & 2.00 & 0.69 & $2-249$ & 2.027 & $.002 *$ \\
\hline Satisfaction & 3.87 & 0.95 & 3.42 & 0.91 & 3.21 & 0.95 & $2-249$ & 4.717 & $.000 *$ \\
\hline
\end{tabular}

Table 4 shows MANOVA results concerning leisure time management and boredom perception in view of participants' ages. Analysis shows as per age variable its basic influence in both leisure time management and leisure boredom perceptions is not significant $\left[\lambda=0.858, \mathrm{~F}_{(12,488)}=3.248, \mathrm{p}>0.05\right]$. But on coefficient level only "Programming" $\left[\mathrm{F}_{(2,249)}=2,304 \mathrm{p}<0.05\right]$ subdimension scores of leisure time management scale displays significant difference. Again on coefficient level when we take a look at leisure boredom perception; "Satisfaction" $\left[\mathrm{F}_{(2,249)}=4.717, \mathrm{p}<0.05\right]$ and "Boredom" $\left[\mathrm{F}_{(2,249)}=2.027, \mathrm{p}<0.05\right]$ subdimensions show significant difference. In both scales, in the subdimensions where a significant difference has been observed, scores of participants between the ages of 17-20 are higher than the scores of participants of other age groups. 
Table 5. MANOVA Test Results as per Participants' Wealth Level

\begin{tabular}{|c|c|c|c|c|c|c|c|c|c|}
\hline & \multicolumn{2}{|c|}{$\begin{array}{c}\text { Low } \\
(N=106)\end{array}$} & \multicolumn{2}{|c|}{$\begin{array}{c}\text { Normal } \\
(N=98)\end{array}$} & \multicolumn{2}{|c|}{$\begin{array}{c}\text { High } \\
(N=48)\end{array}$} & \multirow[b]{2}{*}{ Sd } & \multirow[b]{2}{*}{$\mathbf{F}$} & \multirow[b]{2}{*}{$\mathbf{P}$} \\
\hline & Avg. & Sd & Avg. & Sd & Avg. & Sd & & & \\
\hline Leisure Time Management & 2.29 & 0.77 & 2.51 & 0.54 & 2.52 & 0.64 & $2-249$ & 5.150 & .098 \\
\hline Setting an Objective and Method & 2.29 & 0.92 & 2.26 & 0.84 & 2.39 & 0.76 & $2-249$ & 3.322 & .583 \\
\hline Leisure Time Manner & 1.61 & 0.77 & 1.89 & 0.76 & 2.14 & 0.24 & $2-249$ & 6.489 & $.019 *$ \\
\hline Programming & 2.85 & 0.83 & 3.25 & 0.98 & 3,47 & 0.86 & $2-249$ & 2.827 & $.016 *$ \\
\hline Assessment & 2.41 & 0.26 & 2.64 & 0.90 & 2.77 & 0.63 & $2-249$ & 1.450 & .259 \\
\hline Leisure Boredom Perception & 2.83 & 0.61 & 2.90 & 0.46 & 2.98 & 0.56 & $2-249$ & 3.350 & .732 \\
\hline Boredom & 2.27 & 0.53 & 2.26 & 0.78 & 2.40 & 0.87 & $2-249$ & 6.538 & .475 \\
\hline Satisfaction & 3.40 & 0.48 & 3.31 & 0.96 & 3.49 & 0.85 & $2-249$ & 2.074 & .849 \\
\hline
\end{tabular}

Table 5 shows MANOVA results concerning leisure time management and boredom perception in view of participants' wealth level. Analysis shows as per wealth level variable its basic influence in both leisure time management and leisure boredom perceptions is not significant $\left[\lambda=0.908, \mathrm{~F}_{(12,461)}=2.016, \mathrm{p}>0.05\right]$. But on coefficient level "Programming" $\left[\mathrm{F}_{(2,249)}=2.827, \mathrm{p}<0.05\right]$ and "Leisure Time Manner" $\left[\mathrm{F}_{(2,249)}=6.489, \mathrm{p}<0.05\right]$ subdimension scores of leisure time management scale displays significant difference. In the subdimensions where a significant difference has been observed, participants with higher wealth have higher scores compared to other participants.

Table 6. Correlation Results Between Leisure Time Management Scale and Leisure Boredom Perception Scale

\begin{tabular}{|c|c|c|c|c|c|c|c|}
\hline Subdimensions & & 1 & 2 & 3 & 4 & 5 & 6 \\
\hline Setting and Objective and & $\mathrm{R}$ & 1 & & & & & \\
\hline Method & $\mathrm{P}$ & & & & & & \\
\hline \multirow{2}{*}{ Leisure Time Manner } & $\mathrm{R}$ & ,388 & 1 & & & & \\
\hline & $\mathrm{P}$ & $.000 * *$ & & & & & \\
\hline \multirow{2}{*}{ Programming } & $\mathrm{R}$ & ,128 & .369 & 1 & & & \\
\hline & $\mathrm{P}$ & $.000 * *$ & $.002 * *$ & & & & \\
\hline \multirow{2}{*}{ Assessment } & $\mathrm{R}$ & ,783 & .320 & .446 & 1 & & \\
\hline & $\mathrm{P}$ & $.000 * *$ & $.000 * *$ & $0,00 *$ & & & \\
\hline \multirow{2}{*}{ Boredom } & $\mathrm{R}$ & ,369 & ,388 &, 123 & ,367 & 1 & \\
\hline & $\mathrm{P}$ & $.000 * *$ & $.000 * *$ & $0,00 *$ & $0,00 *$ & & \\
\hline \multirow{2}{*}{ Satisfaction } & $\mathrm{R}$ &,- 163 &,- 355 &,- 131 &,- 154 &,- 327 & 1 \\
\hline & $\mathrm{P}$ & $.000 * *$ & $.004 * *$ & $0,00 *$ & $0,00 *$ & $0,00 *$ & \\
\hline
\end{tabular}

Table 6 shows the results of Pearson correlation test, which was conducted to determine whether a relationship exists between the participants' leisure time management scale and the subdimensions of leisure boredom perception scale. Test results show a negative and significant relationship between leisure time management scale and the "Satisfaction" subdimension of leisure boredom scale $(\mathrm{p}<0.05)$.

\section{Discussion and Conclusion}

Findings of the study, which has been conducted to examine the leisure time management and leisure boredom perception of university students according to some variables and to determine their interrelationship, show that the leisure time management and boredom perception of participants is negative and have a low level.

Assessing the study results within the leisure time management scale, a significant difference has been observed for gender, age and wealth level variables. When we examine the studies conducted to young individuals within the field of study; Kurtepe and Uğurlu (2018) have examined the leisure time management of individuals, who go to a gym as a recreational activity, and they have observed no difference in leisure time management for the gender variable. Eranil and Özcan (2018) have conducted a study, which examines the leisure time management skills of high school students and have observed no difference for the gender variable. Results of those studies and ours are not concordant. Ar1 (2017) has conducted a study, in which the relationship between leisure time management and standard of living of prospective teachers, who are registered to pedagogical formation, has been examined, and it has been observed that the scores of male participants are higher than the scores of female participants in 
"Programming" subdimension. Beville et al. (2014) have conducted a study, which shows that male participants' leisure time management is higher compared to that of female participants. Those results have parallels with the results of our study. When we take a look at the leisure time management of participants as per the age variable, participants between the ages of 17 and 20 have higher scores in "Programming" subdimension compared to the scores of other participants. Leisure time management of individuals with higher wealth level have higher scores compared to participants in other groups. When we check the body of literature, we see that the results of the study conducted by Arı (2017), which examined both age and wealth level variables, have parallels with the results of our study. And it has been noted in the national and international body of literature, findings as per age variable are limited.

When we assess the findings of leisure boredom perception, which is another topic of our study; Aydin et al. (2019) have conducted a study, in which they examined the relationship between leisure boredom perception and mental soundness among prospective teachers, and it shows that the leisure boredom level of male prospective teachers is lower than that of female participants. That study and ours have common points and in the study conducted by Kara et al. (2018), which examines leisure boredom perception, life satisfaction and social attachment levels of prospective PE teachers, and in the study conducted by Yaşartürk et al. (2017), which examines the interrelationship of leisure boredom perception and life satisfaction levels of university students, who engage in recreational activities, show no significant difference as per the gender variable. When we take a look at the leisure boredom perceptions of the sample group in view of their ages, in "Boredom" and "Satisfaction" subdimensions participants between the ages of 17 and 20 have higher scores than the participants of other age groups. In the related body of literature, no finding has been found concerning the age variable. When we examine the findings as per the wealth level variable, results of the study conducted by Kara et al. (2018), and those of our study have parallels, but are not concordant with the results of the study conducted by Yaşartürk et al. (2017).

In conclusion, male university students score higher than female participants in both leisure time management and "Satisfaction" subdimension of boredom perception scale, thus it is possible to claim that they have the skills to manage their leisure time and are therefore satisfied. We could argue that individuals between the ages of 17 and 20 can manage their leisure time. We could argue that wealth level is an important factor with regards to leisure time planning and managing and that it affects leisure time management manner and programming. Finally, we could state that leisure time management and the satisfaction subdimension of leisure boredom perception have a negative correlation.

\section{References}

Ağaoğlu Y. S., \& Eker H. (2006). Türkiye'deki üniversitelerin sağlık, kültür ve spor dairelerinin işlevsel yönden incelenmesi. Spormetre Beden Eğitimi ve Spor Bilimleri Dergisi, IV(4), 131-134. https://doi.org/10.1501/Sporm_0000000071

Akgül, B. M., \& Karaküçük, S. (2015). Boş Zaman Yönetimi Ölçeği (Geçerli Güvenirlik Çalışması). International Journal of Human Science, 12(2), 1867-1880. https://doi.org/10.14687/ijhs.v12i2.3445

Ardahan, F., \& Lapa, Y. T. (2010). Üniversite Öğrencilerinin Serbest Zaman Tatmin Düzeylerinin Cinsiyete ve Gelire Göre İncelenmesi. Hacettepe Üniversitesi Spor Bilimleri Dergisi, 21(4), 129-136.

Arı, Ç. (2017). Pedagojik Formasyonda Kayıtlı Öğretmen Adaylarının Boş Zaman Yönetimleri ve Yaşam Kaliteleri Arasındaki İlişkinin İncelenmesi. Ankara Yıldırım Beyazıt Üniversitesi Sağlık Bilimleri Enstitüsü, Yüksek Lisans Tezi.

Aydın, İ., Öncü, E., Akbulut, V., \& Küçük Kılıç, S. (2019). Öğretmen Adaylarında Boş Zaman Sıkılma Algısı ve Psikolojik Sağlamlık İlişkisi. Atatürk Üniversitesi Beden Eğitimi ve Spor Bilimleri Dergisi, 2(1).

Aydoğan, İ., \& Gündoğdu F. B. (2006). Kadın Öğretim Elemanlarının Boş Zamanlarını Değerlendirme Etkinlikleri. Sosyal Bilimler Enstitüsü Dergisi, 12, 217-232.

Ayhan, C., Ekinci N., Yalçın I., \& Yigit S. (2018). Investigation of Constraints That Occur During Participation In Leisure Activities By High School Students: A Sample Of Turkey. Education Sciences, 8(2), 1-9. https://doi.org/10.3390/educsci8020086

Beville, J. M., Umstattd Meyer, M. R., Usdan, S. L., Turner, L. W., Jackson, J. C., \& Lian, B. E. (2014). Gender differences in college leisure time physical activity: application of the theory of planned behavior and integrated behavioral model. Journal of American College Health, 62(3), 173-184. 
https://doi.org/10.1080/07448481.2013.872648

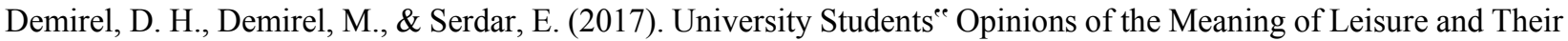
Perceived Freedom in Leisure. Journal of Human Sciences, 14(1), 796-802. https://doi.org/10.14687/jhs.v14i1.4340

Demirel, M., \& Harmandar, D. (2009) Üniversite Öğrencilerinin Rekreasyonel Etkinliklere Katılımlarında Engel Oluşturabilecek Faktörlerin Belirlenmesi. Uluslararası İnsan Bilimleri Dergisi, 6(1), 840.

Demirel, M., Demirel, H., D., \& Serdar, E. (2017). Constraints and perceived freedom levels in the leisure of university students. Journal of Human Sciences, 14(1), 789-795. https://doi.org/10.14687/jhs.v14i1.4340

Eranıl, A. K., \& Özcan, M. (2018). Lise Öğrencilerinin Boş Zaman Yönetimi Becerisinin İncelenmesi. Anemon Muş Alparslan Üniversitesi Sosyal Bilimler Dergisi, 6(6), 779-785.

Gürbüz, B., \& Henderson, K. (2013). Exploring the Meanings of Leisure among Turkish University Students. Croatian Journal of Education, 15(4), 927-957. https://doi.org/10.17718/tojde.54964

Gürbüz, B., Kara, F. M., \& Sarol, H. (2017). Türk Kadınlarının Serbest Zamanda Sıkılma Algısı, Benlik Saygısı ve Yalnızlık Düzeylerinin İncelenmesi. Atatürk Üniversitesi Beden Eğitimi ve Spor Bilimleri Dergisi, 19(4), 188-198.

Howe, C. Z., \& Carpenter, G., M. (1985). Progamming Leisure Experiences. Prentice-Hall Inc., New Jersey, s.3.

Huang C. Y., \& Carleton B. (2003). The relationships among leisure participation, leisure satisfaction and life satisfaction of college students in Taiwan. Journal of Exercise Science and Fitness, 1(2), 129-132.

Iso-Ahola, S. E., \& Weissinger, E. (1987). Leisure and boredom. Journal of Social and Clinical Psychology, 5(3), 356-364. https://doi.org/10.1521/jscp.1987.5.3.356

Iso-Ahola, S. E., \& Weissinger, E. (1990). Perceptions of Boredom in Leisure: Conceptualization, Reliability and Validity of the Leisure Boredom Scale. Journal of Leisure Research, 22(1), 1-17. https://doi.org/10.1080/00222216.1990.11969811

Kara, F. M., Gürbüz, B., \& Öncü, E. (2014). Leisure Boredom Scale: The factor structure and the demographic differences. The Turkish Journal of Sport and Exercise, 16(2), 28-35. https://doi.org/10.15314/TJSE.201428102

Kara, F. M., Gürbüz, B., Küçük Kılıç, S., \& Öncü, E. (2018). Beden Eğitimi Öğretmeni Adaylarının Serbest Zaman Sıkılma Algısı. Yaşam Doyumu ve Sosyal Bağll1ık Düzeylerinin İncelenmesi. Journal of Computer and Education Research, 6(12), 342-357.

Karaküçük, S. (2005). "Rekreasyon” (Boş Zamanları Değerlendirme). Gazi Kitabevi, Ankara, s.60.

Karaküçük, S. (2008). "Rekreasyon” (Boş Zamanları Değerlendirme). Ankara: Gazi Kitabevi.

Karasar, N. (2012). Bilimsel araştırma yöntemi. Ankara: Nobel Akademik Yayıncılık.

Kırtepe, A., \& Uğurlu, F. M. (2018). Rekreatif Amaçlı Spor Salonuna Giden Bireylerin Boş Zaman Yönetimlerinin Farklı Değişkenlere Göre Belirlenmesi. Turkish Studies, 13(3), 783-792. https://doi.org/10.7827/TurkishStudies.13146

Serdar, E., \& Ay, M. S. (2016). Üniversite Öğrencilerinin Serbest Zaman Etkinliklerine Katılım Biçimlerine Göre Tatmin Olma ve Algılanan Özgürlük Düzeylerinin İncelenmesi. Sosyal Bilimler Dergisi, 3(9), 365-374. https://doi.org/10.16990/SOBIDER.3332

Serdar, E., Demirel, M., Demirel, H. D., \& Çakır, V. O. (2017). Üniversite Öğrencilerinin Serbest Zaman Alg1 Düzeyleri İle Problem Çözme Becerileri Arasındaki İlişkiSosyal Bilimler Dergisi. The Journal of Social Science 4(18), 549-560. https://doi.org/10.16990/SOBIDER.3967

Soyer, F., Yıldız, N. O., Harmandar Demirel, D., Serdar, E., Demirel, M., Ayhan, C., \& Demirhan, Ö. (2017). Üniversite Öğrencilerinin Rekreatif Etkinliklere Katılımlarına Engel Teşkil Eden Faktörler ile Katılımcıların Yaşam Doyumları Arasındaki İlişkinin İncelenmesi. Journal of Human Sciences, 14(2), 2035-2046. https://doi.org/10.14687/jhs.v14i2.4647

Wang, W. C., Kao, C. H., Huan, T. C., \& Wu, C. C. (2011). Free Time Management Contributes to Better Quality of Life: A Study of Undergraduate Students in Taiwan. Journal of Happiness Studies, 12(4), 561-573. https://doi.org/10.1007/s10902-010-9217-7

Yaşartürk, F., Akyüz, H., \& Karataş, İ. (2017). Rekreatif Etkinliklere Katılan Üniversite Öğrencilerinin Serbest 
Zamanda Sıkılma Algısı İle Yaşam Doyum Düzeyleri Arasındaki İlişkinin İncelenmesi. International Journal of Cultural and Social Studies, 3(özel sayı), 239-252.

Yaşartürk, F., Akyüz, H., \& Karataş, İ. (2017). Rekreatif Etkinliklere Katılan Üniversite Öğrencilerinin Serbest Zamanda Sıkılma Algısı İle Yaşam Doyum Düzeyleri Arasındaki İlişkinin İncelenmesi. International Journal of Cultural and Social Studies (IntJCSS), 3(SI), 239-252. 